Performing mundane materiality: Actor-Network Theory, global student mobility and a re/formation of 'social capital'

Alfredo Salomão Filho ${ }^{a *}$ and Annelies Kamp ${ }^{\mathrm{b}}$

${ }^{a}$ Institute of Education, Dublin City University, Dublin, Ireland; ${ }^{b}$ College of Education, Health \& Human Development, University of Canterbury, Christchurch, New Zealand

*Corresponding author. Email: alfredo.salomaofilho3@mail.dcu.ie

To cite this article:

Alfredo Salomão Filho \& Annelies Kamp (2019) Performing mundane materiality: Actor-Network Theory, global student mobility and a re/formation of 'social capital', Discourse: Studies in the Cultural Politics of Education, 40:1, 122-135, DOI: $10.1080 / 01596306.2018 .1549708$

Available at:

https://doi.org/10.1080/01596306.2018.1549708 


\title{
Performing mundane materiality: Actor-Network Theory, global student mobility and a re/formation of 'social capital'
}

\begin{abstract}
Social capital is a puzzling actor; made real by its allies. It has been 'out-there' in the form of scientific publications for decades. Although some characteristics are common to all elaborations of this theory (networks, trust, and norms), there remains confusion in determining a 'coherent concept' of social capital. In this paper, we make use of such 'incoherence gap' to open an experimental theoretical and, subsequently, analytical space. Based on empirical research with twelve mobile students in Dublin, and assemblages of non-human actors, the paper offers two investigative gatherings. First, the Bourdieusian approach to 'social capital' is discussed to allow relational ontologies to enter the scene. Second, consideration is given to issues of performativity and the relevance of materiality for empirical social capital investigations. We suggest that anti-essentialist sensibilities offer rigour to examine the actual mobilisation of social capital, rather than speculating its access in potentia. Despite the degree of ontological security social capital has managed to achieve, we question the disregard for the performative role of non-human entities in the context of global student mobility.
\end{abstract}

\section{Introduction}

It would be silly as well as pedantic to abstain from using notions like (...) 'social capital'. But in situations where innovations proliferate, where group boundaries are uncertain, when the range of entities to be taken into account fluctuates, the sociology of the social is no longer able to trace actors' new associations (Latour, 2005, p. 11).

We are social beings. An anthropocentrically framed need for support may have gained acceptance as a fact (Gearin, 2017). However, the position we propose in this article is that articulations of how humans gain support from others, in their pursuit of various forms of capital to aid their endeavours, are inadequate. Social capital is always presented as being relational. But it is not symmetrically relational as its articulation commonly excludes non-human actors. It is our position that the elaboration of more symmetrically relational forms of social capital of the kind invited by Actor-Network Theory (ANT) will be productive given a lack of consensus on what social capital actually is (Gearin, 2017; Ivana, 2017; van Deth, 2008).

Change of the kind experienced by mobile students presents both possibilities and challenges. In the context of global student mobility, change experiences are heightened - as mobility potentially denudes existing networks with their norms and levels of trust. That there are diverse actors that assemble in unique configurations in 
the practices of international education would suggest the need for particular ontological elaborations that are capable of capturing the complexity and ambiguity of those practices. Adopting an ontological perspective that realities are performed in practices generates implications for social capital as a concept. We accept Mol's (2010) invitation to 'betray', or 'play' with, ANT in pursuing this elaboration.

We enact our argument through research on the shifts in social capital of students engaging in international mobility in the course of their higher education. The aim of this article is to rethink the formation, and reformation, of social capital of mobile students. It engages with Bourdieu's (1986) contributions on social capital, and ANT relational ontologies, followed by the analysis of empirical data in light of an experimental and ontologically plural concept of social capital.

We draw on data generated with third-level students from Brazil (now based in Ireland) and their assemblages with non-human actors. We recognise the participation of policy in the enactment of heterogeneous assemblages of global student mobility, however, for the purpose and scope of this article, we follow mobile students. Focusing on student assemblages (or attachment negotiations) does not suggest that policy is relegated to a less relevant role; rather, it is a consequence of the inevitable interplay between presence and absence (Law, 2004).

The article commences by mapping current dialogues between international education and social capital. We then engage with Bourdieu's (1986) forms of capital, paving the way for an elaboration of what we call social capital actor-networks. Despite undisputable differences between ANT and Bourdieu's sociology, the shared - and paradoxical (Schinkel, 2007) - focus on the relational allows an analysis of how social capital is enacted by heterogeneous actors - students and objects - with the more stable assemblages of global student mobility.

\section{Capitalising international education}

Whether a 'big business of international student recruitment' (Knight, 2014, p. 54), or one method of 'encouraging the civic of global citizenship' (Wynveen, Kyle, \& Tarrant, 2012 , p. 335) international education has - over recent years - involved approximately four million students seeking third level education in an international space (Choudaha $\&$ de Wit, 2014). These numbers not only demonstrate the substantiality of this phenomenon, but also give some indication of its centrality to the global flows of actors enacting the 'knowledge society'. In such a society, the potential for interconnectedness among multiple actors - institutions, knowledge, objects and individuals - has never been so possible, so desired, so indispensable.

In the context of the 'knowledge economy', universities arguably have little choice but to answer to the effects of the global environment. The pressures of globalisation and neo-liberal discourses have forced universities to become more organisationally efficient in hyper-competitive landscapes (Brooks \& Waters, 2011). Industrialised countries - including Ireland (DES, 2016) - compete for talented international students who can potentially 'fill the gaps in their knowledge economy' (de Wit \& Merkx, 2012, p. 57), in the process generating lucrative funding streams.

Recent scholarly contributions from the field of global student mobility have considered the day-to-day lives of mobile students, seen as the 'quintessential avatars 
of globalization' (Favell, Feldblum, \& Smith, 2007, p. 16). Encounters with racism (Stein \& Andreotti, 2015), formation of communities of practice (Montgomery, 2010), and adaptation to the 'new context' (Guo \& Chase, 2011) are some of the issues researched. The relationship between social capital and education has also gained scholarly attention in response to the growing utilitarian concern of education in Western societies (Gearin, 2017). Social capital has been used to explore the extent to which mobile students develop forms of capital (Bótas \& Huisman, 2013; Neri \& Ville, 2008; Tran, 2016), and the implications of students' engagement in virtual social networks while studying abroad (Guo, Li, \& Ito, 2014). In each case, this research takes up social capital as a 'ready-made' object (Woolgar \& Lezaun, 2013, p. 323), rather than tracing its composition.

\section{Assembling social capital}

The concept of social capital is related to the idea that social networks offer access to resources that can be used by network members once norms of reciprocity are enacted. Social capital is generally understood as '(1) consisting of structural and cultural aspects, (2) something that requires investments for future goods and actions, and (3) a concept defined by the functions it performs' (van Deth, 2008, p. 152). However, Gearin (2017, p. 605), argues that social capital as a concept has become 'incoherent through contradictory overuse'. Here, we focus on Bourdieu's articulations of social capital due to their degree of influence and innovativeness (Schinkel, 2007). We then move to contribute to a hybrid elaboration of the concept, a symmetrically relational account of social capital enriched by a materialist expansion.

Bourdieu defines social capital as 'the aggregate of the actual or potential resources which are linked to possession of a durable network of more or less institutionalized relationships of mutual acquaintance and recognition' (Bourdieu 1986, p. 51). Individuals deploy strategies in order to form and maintain networks that might accrue material or symbolic profits for their members. A significant contribution from Bourdieu (1986) is related to his elaboration of the relationship between different forms of capital, and the 'specific labour' (ibid) required for the 'conversion' from one form of capital into another (social, cultural, economic, symbolic). This illustrates the transformation from for instance, economic to cultural capital (in the institutionalised form of educational qualification), where time and effort (from one and one's family) are necessary to make such conversion.

It is our position that in international education, or indeed in any aspect of education, social capital - whether as an essence embedded in social relations, or a 'reserve of energy' (Latour, 1986, p. 276) - does not explain much. Rather, social capital is what needs to be explained as an effect, rather than a cause. The issue here is about 'timing' indicating that 'out-thereness' - that is, the acceptance of social capital as a concept - is a consequence of, rather than the cause of, scientific work (Latour \& Woolgar, 1986).

For ANT, social capital - as is any social phenomena - is an effect of heterogeneous associations that then acts on other actors, causing transformation. This suggests that social capital is both an effect of associations and a cause of transformation (has agency): social capital is both cause and effect. We insist on challenging this suggestion; for us, social capital is first an effect. While 'more' social capital can be an effect of social capital, initially, in the first instance, social capital can 
only ever be an effect of an assemblage; an assemblage that includes both human and non-human actors.

The emphasis on issues of 'timing' is important: in order to avoid 'logical circularity' (Portes, 1998, p. 19), or the tautological phantom that has haunted the concept for the last decades (Gearin, 2017). Actors engage in a constant group-making effort, where size is what is at stake (Callon \& Latour, 1981). It is only through gaining 'allies' that a 'thing' becomes real. If entities are brought into existence by their relations, (Latour, 1999a), the latter should be seen - in international mobility - as a performative struggle involving mobile students, classroom teachers, virtual learning environments, visas, education managers, policy and innumerable other actors.

For Bourdieu (1986), the reproduction of social capital requires that actors engage in sociability, where the above-mentioned type of 'work' is needed not only to transform one form of capital into another, but also to generate social capital itself. Wuthnow (2002), for instance, considers the habit of watching television as an inhibitor of social capital in communities, as one would not attend civic meetings when engaged with a television at home. Here, the television is clearly acting; it has gained multiple allies (yet, one might argue, it is now progressively losing them in the digital age).

For example, once engaged in mobility, students negotiate multiple attachments in a new space/reality (Saito, 2010). For these students, the loss of the characteristics of previously formed assemblages demands a new gathering, a new effect. This specific population of actors clearly illustrate the intensity of the performed 'translations' or 'net-work'. The practices of mobile students provide the scope to travel through the series of what we will refer to as social capital actor-networks.

The argument that follows recalls one of ANT's most notable and critiqued elaborations: the rejection of a priori dualism in social science discourse to explain social life. We build on Latour's (1999b, p. 17) provocative thoughts indicating the social as a 'circulating entity' which inevitably troubles the modern constituting properties of society: agency and structure. This is the ontological difference between the more structural, even tautological (Gearin, 2017), Bourdieusian approach to social capital we have surveyed thus far and the one we are elaborating here. Law (1992) and Schinkel (2007) observe that some conceptualisations aimed to propose more dynamic relationships between agency and structure, remaining in-between objectivism and subjectivism, as it is the case in Bourdieu's (1977) Theory of Practice. Yet, the division between the 'domains', although revisited, is retained. Those theorisations are still too 'modern' for ANT, which rejects any 'anonymous field of forces' (Latour, 1999b, p. 19). It is to this concern, and a particular engagement with the work of Bourdieu, that we now turn.

\section{Essentialisation that remains}

For Bourdieu (1986), 'capital' (whether symbolic, financial, cultural or social) is something that humans possess and accumulate, being the responsible force that leads them towards upward mobility, while maintaining (structural) social inequalities. Bourdieu's contributions attach individuals to the class they belong to, transmitting the idea that one 'jumps' from one class to another as one acquires the requisite capital in all its forms. To illustrate, we might consider the respondents in the study on which this article draws. It is only by tracing the trajectory of connections of all actors that one 
can get a more real picture of enactments of social capital, seeing social class - as one actor - not as something that explains phenomena, but as a phenomenon itself, which is generated by the association of heterogeneous actors including, not least, financial resources. Mobility generates ontological messiness, troubling fixed notions of capital (in all its forms) and demanding the analyst to engage in detailed descriptions of how diverse 'things' make us act. This, in turn, depends on the ability and willingness of the actors to disclose information about their personal lives, and the ability of analysts to find what to assist them in such disclosure.

Bourdieu states that 'well known' actors transform 'all circumstantial relationships' into social capital:

(...) the possessors of an inherited social capital, symbolized by a great name, are able to transform all circumstantial relationships into lasting connections. They are sought after for their social capital and, because they are well known, are worthy of being known (...) they do not need to make the acquaintances of all their acquaintances, they are known to more people than they know, and their work of sociability, when it is exerted, is highly productive (Bourdieu, 1986, p. 52).

Let's suppose this is the case with a mobile student who is well known in Brazil but arrives, unknown, in Ireland. There is a possibility that the well-known-in-Brazilstudent will perform less productive work of sociability as this very work will be performed in a newly-produced space which is also performing itself in response to diverse flows. The student will also be in alliance with other actors who constrain, or mobilise, in their search for allies who support their quest to be 'real' in this new space. Instead of seeing a student leaving one structure and moving into another, the task of following and registering the minutiae of transformation is - we argue - the most apposite way to proceed thus, capturing the 'context dependent nature of social capital' (Foley \& Edwards, 1999, p. 146). Here, the composition of 'context' is analysed in itself, rather than taken to be a complete entity into which a student steps.

There are further antagonisms between ANT and Bourdieu's contributions that have methodological implications for social capital. Latour (2005) accuses Bourdieu of always knowing more than the actors themselves - seeing 'reality as it really is' (Mol, 2010, p. 255) - while ANT's principle lies in learning from the actors. ANT accepts the enactment of multiple realities, rejecting the analyst's 'supra capacities' to draw the worlds of the quasi-objects (Latour, 2005). Although not directing his arguments to Latour, Bourdieu (1990, p. 124) classifies the latter's approach as a concern with the 'accounts of the accounts produced by social subjects'. The fact that we focus on each student as the actor being followed corroborates not only our reliance on the accounts given by the actors, but also the position defended by Portes $(1998$, p. 21) that 'the greatest theoretical promise of social capital lies at the individual level' - whatever the individual might be. This analytical attention to the 'micro level', however, should not be mistaken as an emphasis put on the heroic capacities of individuals, and some form of disconnected agency.

The duel between Latour and Bourdieu has received a justified scholarly attention (Guggenheim \& Potthast, 2012). Kale-Lostuvali (2016) argues that 
articulating a comparison between those authors proves to be fruitful as their respective paradigmatic standpoints are so starkly opposed to one another. As Law (2007, p. 11) puts it, we abstain from the desire to 'win' a single 'intellectual space'. Rather, we recognize the experimental nature of our effort to enact 'possibly generative partial connections' between influential opponents (ibid). This is warranted by the absence of criteria for what would be considered as 'meaningful knowledge' (Cilliers, 2005, p. 255), and the idea of knowledge as enactment that emerges from connections among heterogeneous elements (Fenwick \& Edwards, 2014). This opens the thinking space for our concept of social capital actor-networks. In what follows, we invite the reader to join our scholarly experimentation enacted in this article. We need to find a home for the actors, if 'modernism itself is homeless, forcing its inhabitants to dream of a place to live that is uninhabitable' (Latour, 2009, p. 144).

\section{The study}

In our research, we positioned ourselves as the observers (Callon, 1986) of the mobile student net-work - we are the ones who describe what the other actors are doing. However, this ANT case study brings the more stable participation of one of the authors within the actor-networks we are interfering with, and making more 'real'. Drawing an association with Callon (1986), one of the authors is concomitantly a 'scientist' (translator) and a 'scallop/fisherman' (quasi-object). While ANT studies illustrate how scientists inevitably become members of the research-object-net-work (Callon, 1986; Latour, 1988), our study deepens this notion as one of the authors was a mobile student himself: the very first 'entry point' of the fieldwork.

We analysed two rounds of in-depth interviews with twelve Brazilian mobile students in Dublin (three ESOL ${ }^{1}$, three undergraduate, three Master's and three PhD students). The research participants were recruited by snowballing sampling (Waters, 2014), a procedure aligned with the fluid process of assembling a mobile-student-network. The interviews with the students allowed the writing up of individual stories of mobility with a focus on the shifts of social capital performances, demonstrating translation processes that shaped their realities. Attention to the work of mediators (Latour 1999a; 2005) guided the analysis. Our encounter with the data partially followed what Mazzei $(2014$, p. 743$)$ denominates as the process of 'reading-the-datawhile-thinking-the-theory'. Rather than coding empirical data in light of theories and concepts, we sought to make 'new connectives' (ibid), focusing on the experimentation of 'Other' forms of knowledge and the 'betrayal' of ANT itself: the constant effort to follow the actors rather than resorting to prefabricated explanations. The process of consciously pursuing symmetry aimed to enact social capital actor-networks as outthereness (Law, 2004).

As follows, we discuss how an ANTian social capital is achieved via scientific work. The focus on the realities enacted by mobile students and their associations highlights the importance of performativity and heterogeneity in analysing how an actor-network becomes more connected (Latour, 1996).

\footnotetext{
${ }^{1}$ English for Speakers of Other Languages.
} 


\section{Social capital actor-networks}

We have claimed that it is possible to associate, or travel across apparently opposing theoretical boundaries, generating a translated understanding of how mobile students become more or less real when drawing on other actors to enact realities (Bourdieu, 1986; Harman, 2009; Latour, 1999a; Law, 2007; Schinkel, 2007). In this section, we offer some empirical insights into the (re)formation of social capital.

\section{(Dis) connected Actors}

Whereas friends and family somewhere in Brazil were kept mobilised by all students in Ireland (via technological platforms), former employers were disconnected from the majority of the students' actor-networks. The exceptions were Beige ${ }^{2}$ and Yellow, who stated they still had professional contacts in Brazil despite living in Dublin. Students maintain digital 'friendships' that manifest in a personal meeting. Whenever they take holidays in Brazil, they would meet with their former employers to keep the connection 'alive' (Yellow).

Apart from Red and Orange's Brazilian lecturers (providing advice on academic projects being performed in Dublin), for all respondents in the research no non-familial human actor placed in Brazil 'had an impact' on their life in Dublin (Blue). From an ANT perspective, we suggest that this is not completely 'true'. Students understand the world from a Euro-American metaphysics standpoint (Law, 2004), not acknowledging, for instance, that their inscriptions of educational qualifications - or 'cultural capital' (Bourdieu, 1986) - were produced by heterogeneous actors, including humans.

Considering non-human actors, a reference letter from their former lecturers in the cases of Purple and Grey - influenced the enactment of realities in Dublin (Purple used it for his PhD application, while Grey used it for his Master's application). Grey also pointed out his secondary school transcript as 'something' from Brazil which influenced his life in Dublin, as corporate actors in the form of his employer-to-be requested the document. The agency exerted by such document on the employer alters the nature of the assemblage. The student, with his transcript, becomes another actor; a more employable actor in the eyes of the employer (accordingly, the transcript also alters its nature).

\section{Strategies of enrolling actors}

Mobile students tend to negotiate the formation of new social groups in the beginning of their experience in the host country (van Mol \& Michielsen, 2015). The need for support for those sailing in uncharted waters is evident. Information about the specificities of education, work and other actor-networks, including housing, transportation, visa, social and cultural norms - when not already provided by travel agencies and educational institutions - needs to be gathered, generated, processed and

\footnotetext{
${ }^{2}$ The use of colours have no specific meaning, being employed only to guarantee the anonymity of the participants.
} 
reassembled, making students act in ways they might not previously have been able to act or precluding them from acting in ways they might previously desired.

The extent to which students struggle to enroll heterogeneous actors in order to make their actor-network more densely connected varies, but it is possible to affirm that all informants employed a number of strategies that contributed to such processes. Mobile students - as much as migrants (Margolis, 1998) - can favour a location for international education endeavours if they have established allies already living in the destination. This was an actor for Brown, Pink, Purple, and Yellow, students who had friends living in Dublin prior to their arrival. The other eight informants travelled to Dublin on their own and engaged in the process of enrolling in unfamiliar net-work. More actors, such as hopes, money, letters of acceptance, inter alia, travelled along with the human actors.

We highlight the agency of the student visa, a vital inscription device (Latour, 1987) that allows actors to join the more stable assemblage of 'international students', and was an actor that emerged in all the interviews held with our informants. Without a visa, students cannot engage in spatial performances, therefore not being 'real' in the host country. The visa is a fully functioning actor that needs to be taken into consideration for its political, classificatory and paradoxical character - a mediator (Latour, 2005). For the holder, the visa is an enabler of movement, while for the government, it acts as a mechanism of 'ordering' (Law, 1994). Policy is not a mere concern for human actors, but is an actor itself (Fenwick, 2010; Gorur, 2015; Hamilton, 2012; Kamp, 2017). It renders visible what is and what is not possible for mobile students to do abroad. As the visa limits the period in which mobile students can stay in the host country, it may act as a counter-network for those aiming to increase the density of their actor-networks.

The strategies of conducting unfamiliar net-work brings common actors to all students: 'social', 'cultural' 'economic' and 'symbolic' actors. The ontological inseparability among the various forms of capital actor-networks becomes thus, discernible, reinforcing both Bourdieu's understanding that capital can be considered in immaterial forms, and ANT's defence of hybrid ontologies.

Green and Yellow ( $\mathrm{PhD}$ candidates) were particularly fluent in describing their strategy to enroll actors that could translate into a job position in the future. From the perspective of social capital actor-networks, occupational mobility involves more than just a social network articulated by human actors. Virtual platforms, such as LinkedIn, are active players in international education, where the effect of their mobilisation would refer to work opportunities that become available to the actors. For the students, occupational mobility is an effect of an actor-network that managed to become mobilised. Green describes her strategy below

When head-hunters search for you, they go through important people's networks. Because you are not important. But they do like this: 'let me see the important people's contacts, oh...look at her, let's see what she does, oh, she is (supervisor's name)'s PhD student, let's see what she did', so I think everything is actually a strategy, right? You know the people, you get interested in what they do and then you add them in your LinkedIn so... people who get interested in you can find you, so you become relevant. And I try to keep contact with all my networks, that's 
why LinkedIn is important. I meet then I add the person, and even if you don't talk to them, they are there (Green).

The concern in 'finding' a job abroad was not exclusive to $\mathrm{PhD}$ students. English students, such as Lavender, also demonstrated 'intentions' - a result of an array of translations - to mobilise some sort of remunerated activity in Dublin. Mundane objects that would be ignored in more structural, reductionist examinations of social capital - such as student accommodation and bicycles - are given 'voice' in material semiotics due to their demonstrated agential capacity to shape the actions of human actors in unexpected forms; a way to 'resolve' the technical determinist/social constructivist dichotomy when exploring the performance of realities (Latour, 1992; 1999a). We understand the preoccupation with the mundane in social capital debates, as unconventional as it may seem, as a possibility to 'go out and walk new roads' (Mol, 2010, p. 261). Lavender's statement below illustrates this thought.

Overall, people around me helped me when I needed... daily routine things. You need to fix a bike and your housemate takes you to the shop; just to show you the way. In the accommodation, people who are aware of a job vacancy tell the other who needs it in that moment (Lavender).

From a Bourdieusian perspective, we observe how Lavender is receiving benefits as a result of his relationship with his housemates, a field where norms of reciprocity could flourish. The accrued profit is represented by the possibility to fix a bicycle and/or the dissemination of job opportunities, which are understood as outcomes of human relations only. This does not mean that the bike is completely irrelevant to the Bourdieusian appraisal of social capital formation, but relational ontologies invite us to interpret the scene differently, bringing into existence the actors that constitute a course of action, and going beyond causal agency. A bike, as an intermediary, transports us (Latour, 2005). However, given Lavender's description, the bike mutates its 'nature' into becoming a mediator: or an actor that contributes to the unpredictability of human behaviour, such as allowing an invitation from a human actor to accompany another to the bike shop (which could potentially strengthen their relationship). In this sense, the possibility of fixing a bike is not purely the capitalised result of human interaction. Timing is the issue here (Latour \& Woolgar, 1986). The depreciation suffered by the bike affects the translation that approximates human actors. The former is not only an important actor that generates social capital enactments, but potentially a prime-mover (Latour, 1999a), an enabler of a more stabilised assemblage that in turn, may generate positive outcomes to all the actors in the scene. Thinking relationally, the bike legitimately participates in the enactment of social capital actornetworks due to our observance of ANT generalised symmetry (Callon, 1986). This position offers a contrast to a Bourdieusian analysis, which would consider the role played by the bike - if any - as a mere causality of human interaction primarily governed by intentionality and interest.

We now turn to Silver, an undergraduate student, in order to slightly change the focus of the analysis from objects shaping social practices (as they exert more than simply causal agency) to the potential offered by assemblages of 'social capital' to be 
investigated in their intricate detail and complexity, revealing the agential entanglements between human and non-human entities as legitimate constituents of a given collectivity. Although the cold climate and consecutive rainy days 'can make you lazy' - weather is an actor - Silver narrated how he mobilised actors 'in the space of the university', indicating that mobilisation of social capital was partially achieved. He undertook a 'promising' module and decided to ask the lecturer if there was a possibility for continuing studying the subject through a partnership. We asked him to describe what happened.

Silver: This was a Brazilian thing. I knocked on his door and said 'Hi! I loved that module, can we keep studying it together?' And he said 'yes'. We have been meeting every week to discuss the subject. I am sure this will contribute to my undergraduate dissertation when I am back to Brazil. Maybe we can publish together in the future. This was a real network.

Translator: Well done! You went to his office and knocked on the door?

Silver: Yes. I thought about the cultural differences. Will I be invasive if I knock on his door? Then I asked my Brazilian lecturer if I should do that. He told me to be Brazilian and do it.

Translator: To be Brazilian?

Silver: To show initiative. And then I got courage to do so. Maybe I was a bit nosy, I'm not sure. The Irish lecturer already knew me from his class anyways.

Inspired by Law \& Singleton's (2013, p. 491) analysis of the salmon fish farm, we offer a relational ontology lens to describe Silver's 'choreography' of humans and non-humans, illuminating how action is distributed among the elements of the scene described above. The term 'choreography' is particularly illustrative here as our analytical aim is neither to distinguish a priori humans from non-humans, nor to locate the singular source from which action emanates.

The possibility of enacting future long distance academic projects acts on Silver, who goes looking for the Irish lecturer. A closed door, 'a miracle of technology' (Latour, 1992, p. 154), and initial hesitation, led Silver to go looking for advice from his Brazilian lecturer, who then enrolls the actor 'Brazilian culture/identity' that could strengthen Silver's net-work. The act of enrolling the Irish lecturer - inter alia - could exemplify the specificities of this social capital actor-network. However, if the door is not considered, we would not acknowledge a participant in this assemblage, that which Latour (2005, p. 16) denominates 'short cut of social explanation'. The door, as simplistic as it may seem at first glance, is a plausible element in the enactment of this specific social capital actor-network. 
Similarly to Latour's (1999a) analysis of gun control in the U.S., doors have their own goals (or functions). Initially, the door stops Silver (and other actors) from accessing the lecturer's office unproblematically. Here, the non-human disciplines the human as the latter delegates 'values, duties and ethics' to the former (Latour, 1992, p. 157), a thought that is illustrated by Silver's expressed concern with his own ethics ('Maybe I was a bit nosy'). If there was no door, Silver's concern in being 'nosy' could have been potentially lessened. Equivalently, the lecturer who sits in an office without a door would possibly be interrupted more easily by a range of other actors. Humans delegate to the door the role of making other actors occlude for a moment. Silver's enrollment of his Brazilian lecturer was thus necessary to generate the former's action of knocking on the door. The point is that every one of these actions alters the outcome of a particular reality. The attention to the source of action, or the 'prime mover' (Latour, 1999a), is of little importance when analysing material semiotics practices - which could be analogously argued for enactments of social capital. A Bourdieusian approach would elect the Irish lecturer as an actor that constitutes Silver's stock of social capital, focusing on the benefits generated by this newly established social relation. On the other hand, ANTian social capital is concerned with the 'choreography' performed by all actors with detectable agency, which in turn, produces 'social capital'.

The task of describing a course of action in detail is only possible if one considers action as being distributed among heterogeneous actors, agreeing with Latour's suggestion to 'respect the mediating role of all the actants mobilized in the list' (Latour, 1999a, p. 181). Thus, that which is real (door), collective (Silver, Brazilian and Irish lecturers) and narrated (the conversations between human actors) is woven together indistinguishably in ANT - challenging the ontological singularity of all these entities. In this scene, the apparent only way to start mobilising a social capital actornetwork is by knocking on the door. If we resort to the well-rehearsed ANTian concept of obligatory passage point (Callon, 1986), we could attribute to the door the role of a gatekeeper.

If the reader remains doubtful of what the relation between social capital enactments and the existence of a door is, we highlight the role played by Silver's Brazilian lecturer, an ally that performs in this scene due - inter alia - to the existence of a door. We can only speculate if Silver would need his Brazilian lecturer's advice if the Irish lecturer's office had no door at all.

\section{Concluding thoughts}

Objects have always been around - enacting social life - and not only in assemblages of knowledge generation or technological innovations. Objects and the net-work of 'social capital' are inseparable. The encounter between ANT and Bourdieusian social capital generates a series of theoretical and methodological implications for the field of global student mobility. If translation is a new relation between entities that in the process transforms them (Latour, 1999a), we visualise our efforts in translating ANT with social capital as a partial contrast with earlier conceptualisations of both. Despite well documented incompatibilities between Latourian and Bourdieusian approaches (Kale-Lostuvali, 2016; Schinkel, 2007), their common concern with the relational offers a fruitful space for theoretical connectives (Law, 2007). Mol (2010) considers this initiative as being part of the 'art' of ANT, where the idea consists of a shift in 
'existing theoretical repertoires' (ibid, p. 261). Here, we have argued that this kind of flexibility potentially enhances the possibilities for the analyst to describe nontautological events, assemblages, and gatherings of possibility, that were not previously considered, or that would be seen as uninteresting from non-relational perspectives. Associating the teachings of ANT to social capital creates a hybrid theoretical blend that embraces all the actors that demonstrate agential capacity, rather than relying on the quasi-objective movements individuals make across social structures as they acquire diverse forms of capital (Bourdieu, 1986). It is also more overtly concerned with the malleability and singularity of interactions (translations), advocating the description of minutiae relations and its effects. The fact that social capital is commonly accepted as a bona fide part of the social (Latour, 2005) can create confusion. It is real, but not immutable.

The partial connection between modern and unmodern ontologies extends the possibilities of ANT to travel through thus far unexplored terrains in the field of education. These would include the examination of the 'logic of tactics' (Law, 2015) of social capital in global student mobility, and the focus on mobile students as translators. The analysis of the 'net-work' of mobile students configures not only an attempt to 'play' with ANT itself (Mol, 2010), but also to shed light on various categorical moves and searches for 'the' capital associated with global student mobility. This aspiration is significant as it enhances understandings - from the shortest analytical distance possible - of how international education realities unfold. Mobile students negotiate the enactment of a particular reality: a more favourable reality that requires the mobilisation of a heterogeneous (and mundane) collectivity.

\section{Acknowledgements}

We would like to thank the reviewers for their great feedback on the manuscript.

\section{Disclosure statement}

No potential conflict of interest was reported by the authors.

\section{References}

Bótas, P. C. P., \& Huisman, J. (2013). A Bourdieusian analysis of the participation of Polish students in the ERASMUS programme: cultural and social capital perspectives. Higher Education, 66(6), 741-754.

Bourdieu, P. (1977). Outline of a theory of practice. Cambridge, UK: Cambridge University Press. 
Bourdieu, P. (1986). The forms of capital. In J. G. Richardson (Ed.), Handbook of theory and research for the sociology of education (pp. 241-258). New York: Greenwood Press.

Bourdieu, P. (1990). In other words: essays towards a reflexive sociology. Stanford: Stanford University Press.

Brooks, R., \& Waters, J. (2011). Student mobilities, migration and the internationalization of higher education. London: Palgrave Macmillan.

Callon, M. (1986). Some elements of a sociology of translation: domestication of the scallops and the fishermen of St Brieuc Bay. In J. Law (Ed.), Power, action and belief: a new sociology of knowledge (pp. 196-223). London: Routledge \& Kegan Paul.

Callon, M., \& Latour, B. (1981). Unscrewing the big Leviathan: how actors macrostructure reality and how sociologists help them to do so. In K. D. KnorrCetina \& A. V. Cicourel (Eds.), Advances in social theory and methodology: toward an integration of micro- and macro-sociologies (pp. 277-303). Boston, Massachusetts: Routledge and Kegan Paul.

Choudaha, R., \& de Wit, H. (2014). Challenges and opportunities for global student mobility in the future: a comparative and critical analysis. In B. Streitwieser (Ed.), Internationalisation of higher education and global mobility (pp. 19-33). Oxford: Symposium Books.

Cilliers, P. (2005). Complexity, deconstruction and relativism. Theory, Culture \& Society, 22(5), 255-267.

De Wit, H., \& Merkx, G. (2012). The history of internationalization of higher education. In D. Deardoff, H. de Wit, J. Heyl \& T. Adams (Eds.), The Sage handbook of international education (pp. 43-60). Thousand Oaks: Sage.

DES Department of Education and Skills (2016). Irish educated globally connected: an international education strategy for Ireland 2016 - 2020. Retrieved from: https://www.education.ie/en/Publications/Policy-Reports/InternationalEducation-Strategy-For-Ireland-2016-2020.pdf.

Favell, A., Feldblum, M., \& Smith, M. P. (2007). The human face of global mobility: a research agenda. Society, 44(2), 15-25.

Fenwick, T. (2010). (Un)doing standards in education with Actor Network Theory. Journal of Education Policy, 25(2), 117-133.

Fenwick, T., \& Edwards, R. (2014). Networks of knowledge, matters of learning and criticality in higher education. Higher Education, 67(1), 35-50.

Foley, M. W., \& Edwards, B. (1999). Is it time to disinvest in social capital? Journal of Public Policy, 19(2), 141-173.

Gearin, B. (2017). The mismeasure of monkeys: education policy research and the evolution of social capital. Journal of Education Policy, 32(5), 604-627. 
Gorur, R. (2015). Producing calculable worlds: education at a glance, Discourse: studies in the cultural politics of education, 36(4), 578-595.

Guggenheim, M., \& Potthast, J. (2012). Symmetrical twins: On the relationship between Actor-Network theory and the sociology of critical capacities. European Journal of Social Theory, 15(2), 157-178.

Guo, S., \& Chase M. (2011). Internationalisation of higher education: integrating international students into Canadian academic environment. Teaching in Higher Education, 16(3), 305-318.

Guo, Y., Li, Y., \& Ito, N. (2014). Exploring the predicted effect of social networking site use on perceived social capital and psychological well-being of Chinese international students in Japan. Cyberpsychology, Behavior and Social Networking, 17(1), 52-8.

Hamilton, M. (2012). What a sociology of translations can offer to educational policy analysis. In T. Fenwick \& R. Edwards (Eds.), Researching education through Actor Network Theory (pp. 40-60). UK: Wiley-Blackwell.

Harman, G. (2009). Prince of networks Bruno Latour and metaphysics. Melbourne: Re.Press.

Ivana, G. I. (2017). Fake it till you make it: imagined social capital. The Sociological Review, 65(1), 52-66.

Kale-Lostuvali, E. (2016). Two sociologies of science in search of truth: Bourdieu versus Latour. Social Epistemology, 30(3), 273-296.

Kamp, A. (2017). Assembling the actors: exploring the challenges of 'system leadership' in education through Actor-Network Theory. Journal of Education Policy, doi: 10.1080/02680939.2017.1380231.

Knight, J. (2014). Three generations of cross-border higher education: new developments, issues and challenges. In B. Streitwieser (Ed.), Internationalisation of higher education and global mobility (pp. 43-58). UK: Symposium Books.

Latour, B. (1986). The powers of association. In J. Law (Ed.), Power, action and belief: a new sociology of knowledge (pp. 264-80). London: Routledge \& Kegan Paul.

Latour, B. (1987). Science in action. Cambridge: Harvard University Press.

Latour, B. (1988). Mixing humans and nonhumans together: the sociology of a door closer. Social Problems, 35(3), 298-310.

Latour, B. (1992). Where are the missing masses? The sociology of a few mundane artifacts. In J. Law \& W. Bijker (Eds.), Shaping technology/building society (pp. 225-259). Cambridge: MIT Press.

Latour, B. (1996). On Actor-Network Theory: a few clarifications plus more than a few complications. Soziale Welt, 47, 369-381. 
Latour, B. (1999a). Pandora's hope: essays on the reality of science studies. Cambridge MA: Harvard University Press.

Latour, B. (1999b). On recalling ANT. In J. Law \& J. Hassard (Eds.), Actor Network Theory and after (pp. 15-25). Oxford: Blackwell.

Latour, B. (2005). Reassembling the social: an introduction to Actor-Network-Theory. Oxford: Oxford University Press.

Latour, B. (2009). Spheres and networks: two ways to reinterpret globalization. Harvard Design Magazine, 30(Spring/Summer), 138-144.

Latour, B., \& Woolgar, S. (1986). Laboratory life: the construction of scientific facts. (2nd ed.). Princeton, NJ: Princeton University Press.

Law, J. (1992). Notes on the theory of the Actor-Network: ordering, strategy, and heterogeneity. Systems Practice, 5(4), 379-393.

Law, J. (1994). Organizing modernity. Oxford: Blackwell.

Law, J. (2004). After method: mess in social science research. London: Routledge.

Law, J. (2007). Actor Network Theory and material semiotics. Retrieved from: http://www.heterogeneities.net/publications/Law2007ANTandMaterialSemioti cs.pdf

Law, J. (2015). STS as Method. Retrieved from: http://heterogeneities.net/publications/Law2015STSAsMethod.pdf

Law, J., \& Singleton, V. (2013). ANT and politics: working in and on the world. Qualitative Sociology, 36(4), 485-502.

Margolis, M. (1998). An invisible minority: Brazilians in New York City. Boston: Allyn and Bacon.

Mazzei, L. A. (2014). Beyond an easy sense: a diffractive analysis. Qualitative Inquiry, 20(6), 742-746.

Mol, A. (2010). Actor-Network Theory: sensitive terms and enduring tensions. Zeitschrift Für Soziologie, 50(1), 253-269.

Montgomery, C. (2010). Understanding the international student experience. Hampshire: Palgrave Macmillan.

Neri, F.V., \& Ville, S. (2008). Social capital renewal and the academic performance of international students in Australia. Journal of Socio-Economics, 37(4), 15151538 .

Portes, A. (1998). Social capital: its origins and applications in modern sociology. Annual Review of Sociology, 24,1-24. 
Saito, H. (2010). Actor-Network Theory of cosmopolitan education. Journal of Curriculum Studies, 42(3), 333-351.

Schinkel, W. (2007). Sociological discourse of the relational: the cases of Bourdieu \& Latour. The Sociological Review, 55(4), 707-729.

Stein, S., \& Andreotti, V.O. (2015). Cash, competition, or charity: international students and the global imaginary. Higher Education, 72(2), 225-239.

Tran, L. T. (2016). Mobility as "becoming": A Bourdieuian analysis of the factors shaping international student mobility. British Journal of Sociology of Education, 37(8), 1268-1289.

Van Deth, J. W. (2008). Measuring social capital. In D. Castiglione, J. W. van Deth \& W. Guglielmo (Eds.), Handbook of social capital (pp. 150-176). Oxford: Oxford University Press.

Van Mol, C., \& Michielsen, J. (2015). The reconstruction of a social network abroad: an analysis of the interaction patterns of Erasmus students. Mobilities, 10(3), $423-444$.

Waters, J. (2014). Snowball sampling: a cautionary tale involving a study of older drug users. International Journal of Social Research Methodology, 18(4), 367-380.

Woolgar, S., \& Lezaun, J. (2013). The wrong bin bag: a turn to ontology in science and technology studies? Social Studies of Science, 43(3), 321-340.

Wuthnow, R. (2002). The United States: bridging the privileged and the marginalized? In R. Putnam (Ed.), Democracies in flux: the evolution of social capital in contemporary society (pp. 59-102). Oxford: Oxford University Press.

Wynveen, C. J., Kyle, G. T., \& Tarrant, M. (2012). Study abroad experiences and global citizenship: fostering proenvironmental behavior. Journal of Studies in International Education, 16(4), 334-352. 